\title{
THE ANALYSIS OF FIGURATIVE LANGUAGE IN "GIRL ON FIRE" SONG LYRICS BY ALICIA KEYS
}

\author{
Indra Sopiansyah ${ }^{1}$, Ratih Inayah2 ${ }^{2}$ \\ 1,2 IKIP Siliwangi \\ 1 indrademircan@student.ikipsiliwangi.ac.id, ${ }^{2}$ ratih.inayah@gmail.com
}

\begin{abstract}
Figurative languages are languages that use figures of speech, not literal meanings. This research analyzed the figurative language used in the lyric of Girl on Fire by Alicia Keys. The purpose of this research is to find out the types of figurative language in the lyrics of the song Girl on Fire by Alicia Keys and to analyze the contextual meaning of figurative language used in that song lyrics. It is hoped that the results of this study will be useful for readers, especially in describing what figurative language and what kind of figurative language are. The method of this research is descriptive qualitative research. The lyrics of song is got from (Keys, 2012) entitle Girl on Fire. The result found that there are some kinds of figurative language used in Alicia Keys' song entitle Girl on Fire, such as alliteration, cliché, hyperbole, idiom, imagery, metaphor, personification, repetition, similie, and symbol. The contextual meaning of each figurative language is also clarified. The conclusion of this research is there are some kinds of figurative language use by Alicia Keys in her song titled Girl on Fire.
\end{abstract}

Keywords: Literature, Figurative Language, Song, Lyric, Contextual Meaning

\section{INTRODUCTION}

Language is the key or tool for humans to communicate with each other. Without language, humans will never able to communicate with others. In addition, humans need language to interact, to search and giving people useful information. Language is needed to be understood what the goals it is going to be and to convey ideas and information through oral or written (Aprianti \& Parmawati, 2020). According to (Meyer, 2018) as cited in (Setiawati \& Maryani, 2018) literature is a term used to describe written texts characterized by careful use of language, including features such as creative metaphors, beautiful phrase, elegant syntax, rhymes, and aesthetic alliterations. The author intends to read himself aesthetically and deliberately slightly open in interpretation.

Language works in all aspects of life. One of them is in literature. According to Griffee (2001) as cited in (Setiawati \& Maryani, 2018) that song is part of music that is formed through words that aims to be sung. Most literary writers use it to express their thoughts, feelings, emotions, and imagination. A song has an appeal and attracts the listener's interest and is usually made by professional composers and song writers. There are many messages conveyed by songs. Through songs people can convey their messages and feelings to others by singing. People can communicate with others through songs. In other words, songs can be used as a way to convey messages and feelings, so that people can understand what the composer or song writer means. Song lyrics are one example of literature. The lyrics of the song are meaningful. The writers can express their feelings in the lyrics. It cannot be taken literally. This means that the writer uses figurative language. 
According to Mario Klarer (2004:2) as cited in Amanda Putri \& Bejo Sutrisno (2017) Poetry is one of the oldest genres in literature history. Its earliest examples go back to ancient Greek Literature. In spite of this long tradition, it is harder to define the any other genre. Poetry is closely related to the term "lyrics" which is etymologically derived from the Greek musical instrument "lyra" ("lyre" or "harp") and points to an origin in the sphere of music. In classical times as well as in medieval lyre and other musical instruments used as accompaniment musical instruments when poets recite poetry. The term "poetry", however, goes back to the Greek word "poico" ("to make to reduce"), indicating that the poet is the person who "makes" verse. Although etymology has seen several aspects of lyrics and poetry, etymology cannot provide a satisfying explanation about such a phenomenon. Figurative language is language using figures of speech not literal means, so we cannot take it literally. Therefore, the meaning in figurative language is not fully reflected in the words that compose it. Figurative language takes several forms, such as metaphor, simile, personification, hyperbole, idiom, and euphemism. In general, figurative language can be divided into four groups namely allusions,confirmations, comparisons, and oppositions. These figurative languages are famous in society, and also in the field of education starting from elementary school up to the university level.

Poetry In British Literature and American Literature ( Bajraktari et.al, 2008) a poem is commonly defined as a composition written in verse (although verse has been equally used for epic and dramatic fiction). Poems rely heavily on imagery, precise word choice, and metaphor; they may take the form of measures consisting of patterns of stresses (metric feet) or of patterns of different-length syllables (as in classical prosody); and they may or may not utilize rhyme. One cannot readily characterize poetry precisely. Typically though, poetry as a form of literature makes some significant use of the formal properties of the words it uses - the properties attached to the written or spoken form of the words, rather than to their meaning. Metre depends on syllables and on rhythms of speech; rhyme and allitaration depend on words that have similar pronunciation. Some recent poets, such as e.e.cummings, made extensive use of words' visual form.

There is hidden meaning in song lyrics. Song lyrics use not literal words, compared to words used in everyday conversation. The lyrics use figurative language to make their own meaning; if we can interpret it the meaning can seem deeper. While the listener knows the meaning of the lyrics it will have its own opinion. Therefore, everyone will interpret it with their own understanding without knowing the truth or appropriateness of the meaning of the song with the songwriter or composer. Lyrics in music are not only used for denotative meanings to express the message of the song, but also connotative meanings. Connotative meaning occurs because the singer wants to make a deal, disagree, happy, unhappy, etc. for the listener. Beautiful and strong words will have valuable meanings and require the ability to convey messages through figurative language in song lyrics. One way to understand the meaning of speech and to avoid various interpretations can be to use figurative language

Tarigan (Azwardi, 2016) as cited in (Setiawati \& Maryani, 2018) figurative languages are forms of language used by authors or speakers delivering something beyond the literal meaning. In studied the implicit meaning of language or utterances in songs created by song-writer so that the readers or listeners can feel and realize that aims.

Alicia Keys, a musician who was born January 25, 1981 with the real name Alicia Augello Cook Dean is not only known as a musician, but she is also an actress, pianist, and also a coldhanded American record producer. She is an American R\&B, soul, hip hop and pop singer. She sings in many genres, but is more commonly known as an $R \& B$ singer. The song Girl on Fire 
is a song that was released in 2012 is a song that is in her $5^{\text {th }}$ album of the same name which entered the Billboard 200 topping, released a successful song title, and won a Grammy Award for Best R\&B Album. In 2013, VH1 Storytellers was released as her second live album. Because of an interest in figurative language research, this research is focused on the figurative language used primarily in the lyrics of the song Girl on Fire by Alicia Keys.

In addition to the reasons mentioned above, researchers chose her because in her songs have many hidden meanings, so the researchers wants to investigate more deeply to be able to know the meaning. As for aims this research to know: Types of figurative language is used in Alicia Keys song and the contextual meaning of figurative language used in Alicia Keys song lyrics. In this research, the researcher takes the data from Alicia Keys song lyrics "Girl on Fire" from her $5^{\text {th }}$ studio album of the same name.

\section{THEORETICAL FRAMEWORK}

\section{Figurative Language}

According to Christopher Russell Reaske (1966 : 22) defines figurative language as a language that uses various figures of speech. Some examples are antithesis, cliché, hyperbole, metaphors, paradoxes, similes, and etc. In general, figurative language is a type of language that is different from the language used in everyday life and is literal to describe people from objects. Using figurative language creates imaginative descriptions in different ways with power words. There are many types of figurative language:

a. Alliteration

In (Cox, 2000), alliteration repeating consonant sounds in fairly close proximity to each other, like "Peter Piper Picked" or "Mary took Mama to the market today" or You're my body and bone / my one and only baby / but oh you're double the trouble" and so on.

b. Cliché

According to Knapp and Watkins, (2005: 53-55) as cited in (Kurniawan et al., 2014) Clichéee is generally a pejorative term for the use of a word or phrase, or a figure of speech like a simile or metaphor, that has lost its effect through overuse. For example, Thick as a brick, seriously speaking, he fought like a demon, she was a jewel.

c. Hyperbole

According to Christopher Russell Reaske (1966:23) Hyperbole is a figure of speech which employs exaggeration. Hyperbole differs from exaggeration in that it is extream or excessive.

d. Idiom

According to (Loreto Todd, 1987:86) as cited (Putri \& Sutrisno, 2017) An idiom is a group of words whose meaning can not be explained in term of the habitual meanings of the words that make up the piece of language. Thuse fly of the handle which means lose one temper can not be understood in term of the meaning of fly, off or handle.

e. Imagery 
According to (Stern \& Stern, 2013) imagery in a literary text, is an author's use of vivid and descriptive language to add depth to their work. Sensory imagery appeals to human senses to deepen the reader's understanding of the work. Powerful forms of imagery engage all of the senses.

f. Metaphor

A metaphor uses words to describe something as if it actually is something else, for example: "her eyes are stars in the dark sky of my heart" or "the wind is a howling ghost tonight"(Cox, 2000).

g. Personification

Personification is used to describe or speak of a thing or place as if it were a person, like some people talk about their car (Cox, 2000). Example:

Old Bessie, she had nerves of steel

And she never steered me wrong

she carried me through miles of years

and no road was ever too long-

I'm gonna miss her now that she's gone

h. Repetition

(McDaugal,2002) leading to page 683, repetition is the technique using a sound, a word, a phrase, or a sence over again for emphasis.

i. Similie

Similie is an expression that compares one thing to another using the word "like" or "as" : "her eyes were like stars to a heart dark as the sky" or "the sunset gleamed purplish pink like a bruise across the sky" (Cox, 2000).

j. Symbol

Chistopher Russell Reaske (1996:25) states that a symbol may be private (it is meaning known only to one person) original (it is meaning defined by it is context in a particular word), or traditional ( it is meaning defined by your common culture and heritage), and symbole my be all of those definitions.

\section{Song}

Stephen Rampur (2015) leading to page 36, states that a song is a single (and often standalone) work of music intended to be sung by the human voice with distinct and fixed pitches and patterns using sound and silence and a variety of forms that often include the repetition of sections. A song combines words and melody in particular time and rhythmic structure to express feelings, thoughts, dreams, intentions or actions of particular person or persons (Cox, 2000). The two bsic components of song are words and melody.

\section{Lyric}

Lyrics are a set of words that make up a song, usually consisting of verses and choruses. The writer of lyric is a lyricist. Libretto is a word for expanded musical compositions such as opera and librettist is the term for the author. The meaning of lyric can either be explicit or implicit. Some lyrics are abstract, almost an 
unintelligible, and in such cases, their explication emphasizes form, articulation, meter, and symmetry of expression (Alfred Mann, 2000:30).

There are several studies which have done by previous researchers, from analyzing figurative language (Putri \& Sutrisno, 2017) they found the figurative languages in the Justin Timberlakees selected song are "symbol, metaphor, personification and simile. another study was also conducted by Apriono (2017) in his research entitled Analysis of Figurative Languages Used in Scorpion Song Lyrics. He analyzed from two Scorpion album songs, Crazy World and Love. He found 23 hyperbole, 8 personifications and apostrophes, 2 similes, 1 paradox and 1 statement. Hyperbole is the most dominant figurative language found in Scorpion songs. The figurative language function found in the Scorpion song lyrics is the language or phrase used verbally to describe the intentions, ideas, or messages of a speaker.

\section{METHOD}

In analyzing figurative language in Alicia Keys song lyrics, the writers focus on figurative language; using qualitative research methodology. The data for this analysis is taken from several books, the internet as well as the lyrics, and to add resources to this research, the writer listens to the song from Alicia Keys.

\section{RESULTS AND DISCUSSION}

\section{Results}

This is part is a process analyzing from the data taken. The writers take the data from the song lyric „Girl on Fire ${ }^{e e}$ by Alicia Keys. The process is divided into three parts. First is the lyrics to the song "Girl on Fire" by Alicia Keys', the second is figurative language types in the lyrics of the song "Girl on Fire" by Alicia Keys", and the third is the Meaning of figurative language.

Table 1.

\section{The Figurative Language}

\begin{tabular}{|c|c|c|c|}
\hline No. & $\begin{array}{c}\text { Types of Figurative } \\
\text { Language }\end{array}$ & Lyrics & Meaning \\
\hline 1. & Alliteration & $\begin{array}{l}\text { "Burn, Baby. Burn, } \\
\text { Baby!". These lyrics } \\
\text { repeating the "b" } \\
\text { sound at the } \\
\text { beginning of each } \\
\text { word. }\end{array}$ & $\begin{array}{l}\text { It can be } \\
\text { said that } \\
\text { women can } \\
\text { control } \\
\text { themselves } \\
\text { in their } \\
\text { loneliness. } \\
\text { She's going } \\
\text { to do thing } \\
\text { and kill it } \\
\text { even if she's } \\
\text { alone. } \\
\end{array}$ \\
\hline 2. & Cliché & $\begin{array}{l}\text { - "She got her head in } \\
\text { the clouds". }\end{array}$ & $\begin{array}{l}\text { She got } \\
\text { herself up } \\
\text { high now. }\end{array}$ \\
\hline
\end{tabular}




\begin{tabular}{|c|c|c|c|}
\hline & & $\begin{array}{l}\text { - “On top of the } \\
\text { world". }\end{array}$ & $\begin{array}{l}\text { She is on } \\
\text { top of her } \\
\text { success. } \\
\end{array}$ \\
\hline & Hyperbole & $\begin{array}{l}\text { - "Everybody stares } \\
\text { as she goes by". } \\
\text { "Ohhh, got our head } \\
\text { in the clouds". }\end{array}$ & $\begin{array}{l}\text { It is an } \\
\text { exaggeration } \\
\text { of how } \\
\text { many people } \\
\text { stare, it's } \\
\text { not meant to } \\
\text { be taken } \\
\text { seriously } \\
\text { that } \\
\text { absolutely } \\
\text { everyone is } \\
\text { staring at } \\
\text { her. } \\
\text { They got } \\
\text { what they } \\
\text { wanted and } \\
\text { tried to keep } \\
\text { it. }\end{array}$ \\
\hline & Idiom & $\begin{array}{l}\text { "Ohhh, she got her } \\
\text { head in the clouds". }\end{array}$ & $\begin{array}{l}\text { By ignoring } \\
\text { all the pain } \\
\text { she knows it } \\
\text { will } \\
\text { disappear. } \\
\end{array}$ \\
\hline & Imagery & $\begin{array}{l}\text { "So bright she can } \\
\text { burn your eyes". }\end{array}$ & $\begin{array}{l}\text { Women who } \\
\text { have high } \\
\text { spirits, } \\
\text { desires so } \\
\text { that they } \\
\text { can inspire } \\
\text { others. }\end{array}$ \\
\hline & Metaphor & $\begin{array}{l}\text { - "She's just a girl } \\
\text { and she's on fire". } \\
\text { - "Feeling the } \\
\text { catastrophe". }\end{array}$ & $\begin{array}{l}\text { - All powerful } \\
\text { women that } \\
\text { have a } \\
\text { strong mind } \\
\text { and are } \\
\text { willing to } \\
\text { stand up for } \\
\text { them selves. } \\
\text { - Her fame } \\
\text { and her } \\
\text { amazing } \\
\text { personality } \\
\text { is getting the } \\
\text { best of her. }\end{array}$ \\
\hline & Personification & - "She can fly away". & $\begin{array}{l}\text { - By ignoring } \\
\text { the pain she }\end{array}$ \\
\hline
\end{tabular}




\begin{tabular}{|c|c|c|}
\hline & $\begin{array}{l}\text { - 'She's not backing } \\
\text { down }\end{array}$ & $\begin{array}{l}\text { knows it will } \\
\text { all } \\
\text { disappear. } \\
\text { You can't } \\
\text { stop her } \\
\text { anymore. }\end{array}$ \\
\hline 8. $\quad$ Repetition & $\begin{array}{l}\text { - "This girl is on fire". } \\
\text { Repetition is the } \\
\text { technique using a } \\
\text { sound, a word, a } \\
\text { phrase, or a scene } \\
\text { over again for } \\
\text { emphasis. These } \\
\text { same lyrics are } \\
\text { repeated multiple } \\
\text { times so we can } \\
\text { remember the } \\
\text { purpose of the song } \\
\text { theme. }\end{array}$ & $\begin{array}{l}\text { She is in her } \\
\text { passion for } \\
\text { success }\end{array}$ \\
\hline 9. Similes & $\begin{array}{l}\text { - "Lonely like a } \\
\text { highway". } \\
\text { Comparing "she" } \\
\text { and "highway" } \\
\text { using the word } \\
\text { "like". }\end{array}$ & $\begin{array}{l}\text { Feels alone } \\
\text { and terrible } \\
\text { but she's } \\
\text { doesn't care. }\end{array}$ \\
\hline 10. Symbol & $\begin{array}{l}\text { "Fire" (The girl is } \\
\text { not literally on fire. }\end{array}$ & $\begin{array}{l}\text { Fire represents } \\
\text { spirit and burning } \\
\text { intensity }\end{array}$ \\
\hline
\end{tabular}

\section{CONCLUSION}

From analyzing figurative language not only found lyrics consisting figurative language but also the meaning of the song's lyrics. And then the writer knows what the speaker (singer) is trying to express or say. In analyzing the song and will summarize the entire text of the song's lyrics and get the meaning of the song. "Girl on Fire" is about women who find their own inner strength and channel it in a way she has never tried before. Being "on fire" means giving herself the freedom to take full control of who she is and how she wants to live her life. Figurative language is found in the lyrics of the song "Girl on Fire" by Alicia Keys are alliteration, clichés, hyperbole, idiom, imagery, metaphor, personification, repetition, similes, and symbolism.

\section{ACKNOWLEDGMENTS}

Alhamdulillahi rabbil 'alamin, the researcher expressed his highest gratitude to Allah Subhanahu wa ta'ala for his blessings, love, opportunity, health, and mercy to finish this article. This article entitled "The Analysis Of Figurative Language In Girl on Fire Song Lyrics by Alicia Keys" is submitted as the final requirement in accomplishing research paper at English Education Study Program Language And Arts Department IKIP Siliwangi Bandung. 


\section{REFERENCES}

Aprianti, I. N., \& Parmawati, A. (2020). Derivational And Inflectional Morpheme Analysis On The Song Lyrics Of Lady Gaga "A Star Is Born” Album. Project (Professional Journal Of English Education), 3(3), 322-328.

Bajraktari, G., Duncan, A., Pepper, J., Henein, M., Campobasso, C. P., Dell'Erba, A. S., ... \& Zotti, F. (2008). Bibliography Current World Literature Vol 15 No 5 October 2009. Echocardiography, 9, 779-783.

Keys, A., Babyface, Dixon, A., Dr. Dre, Jerkins, R., Maxwell, ... \& Beatz, S. (2012). Girl on fire. RCA records.

Kurniawan, D. (2014). An Analysis of Figurative Language in Scorpion Song Lyrics and Its Application In Elt For Junior High School Students (Doctoral dissertation, Bahasa Inggris-FKIP).

Lafrenière, D., \& Cox, S. M. (2013). 'If you can call it a poem': toward a framework for the assessment of arts-based works. Qualitative Research, 13(3), 318-336.

Meyer, J. (2018). What is Literature? A Definition Based on Prototypes. Work Papers of the Summer Institute of Linguistics, University of North Dakota Session, 41(1). https://doi.org/10.31356/silwp.vol41.03

Putri, A., \& Sutrisno, B. (2017). Amanda \& Bejo : A igurative Language Analysis. A Figurative Language Analysis Of Song Lyric „, Mirrors" By Justin Timberlake, 117-138.

Setiawati, W., \& Maryani, M. (2018). an Analysis of Figurative Language in Taylor Swift'S Song Lyrics. PROJECT (Professional Journal of English Education), 1(3), 261. https://doi.org/10.22460/project.v1i3.p261-268

Stern, R. E., \& Stern, R. E. (2013). References 1. Environmental Litigation in China, 58(April 2020), 247-286. https://doi.org/10.1017/cbo9781139096614.011 